\title{
Antibacterial effects of methanolic extracts of Reum ribes L. and Hyssopus officinalis on some standard pathogenic bacteria
}

\author{
Javad Sayyahi $^{1 *}$, Hayedeh Mobaiyen ${ }^{2}$, Behboud Jafari ${ }^{3}$, Abolfazl Jafari-Sales ${ }^{4}$
}

1. Young Researchers and Elite Club, Ahar Branch, Islamic Azad University, Ahar, Iran.

2. Department of Microbiology, Faculty of Medicine, Tabriz branch, Islamic Azad University, Tabriz, Iran.

3. Department of Microbiology, Ahar Branch, Islamic Azad University, Ahar, Iran.

4. Young Researchers and Elite Club, Ahar Branch, Islamic Azad University, Ahar, Iran.

\section{Article Type:}

Original Article

\section{Article History:}

Received: 15 Feb 2019

Revised: 30 Jun 2019

Accepted: 19 Jul 2019

\section{*Correspondence:}

Javad Sayyahi

Young Researchers and Elite Club, Ahar Branch, Islamic Azad University, Ahar, Iran

javad.sayyahi@yahoo.com

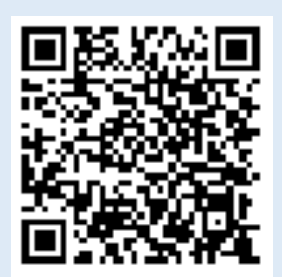

\begin{abstract}
Background and objectives: As much as people become aware of the dangerous side effects of synthetic antibiotics, the demand for natural alternatives to these drugs increases. Natural ingredients, lower risk of complications and even have beneficial side effects. The aim of this study was to determine the antibacterial effect of herbs Reum ribes $L$ and hyssop Hyssopus officinalis is on some pathogenic bacteria.

Methods: After collecting and confirming the scientific name, the methanolic extract of $R$. ribes $L$. and $H$. officinalis plants was prepared and the antimicrobial effects of the extracts by agar well diffusion and disk diffusion, as well as the determination of The minimum bactericidal concentration and the minimum inhibitory concentration (MIC / MBC) were dilution test on Staphylococcus aureus, Bacillus cereus, Escherichia coli and Pseudomonas aeruginosa .

Results: The highest growth inhibitory zone in S. aureus, B. cereus, P. aeruginosa, and E. coli at concentrations of $400 \mathrm{mg} / \mathrm{ml}$, respectively, in the disc method of 13.21, 13.41, 11.2 and $10.74 \mathrm{~mm}$ and the well method, respectively $13.64,13.11,10.67 \mathrm{~mm}$, and 9.38 $\mathrm{mm}$ for the $R$. ribes $L$ extract, and the disc method of $11.74,10.2,10.71$, and $9.1 \mathrm{~mm}$, and the well method of $12.41,11.6,10.2$, and 9.9 respectively. $4.3 \mathrm{~mm}$ was observed for H. officinalis extract. The results of MBC / MIC showed that the extract of medicinal plants had the highest susceptibility to $B$. cereus bacteria and the least susceptibility to $E$. coli.

Conclusion: $R$. ribes $L$. and $H$. officinalis plants have significant inhibitory effects on the growth of pathogenic bacteria in vitro. Therefore, it can be expected that these extracts can be used for the treatment of bacterial infections and are a good alternative to the usual chemical treatments for the treatment of infections.
\end{abstract}

Keywords: Antibacterial effects, Pathogenic bacteria, Medicinal plants, Extract

Copyright $\subseteq$ 2018, Jorjani Biomedicine Journal has published this work as an open access article under the terms of the Creative Commons Attribution License (http://creativecommons.org/licenses/by-nc/4.0/) which permits noncommercial uses of the work while it is properly cited. 


\section{Introduction}

Medicinal plants during the development of all human civilizations, there has always been a close relationship between man and plant. Although most plant species are known to date, there is still much time left to discover new and valuable plant resources (1-4). As such, plants can be a useful source of chemicals that are only partially identified. These chemicals can be used as a drug but also as a unique starting point for the manufacture of pharmaceutical analogues, as well as an interesting tool to better understand a biological phenomena (5-7). Rheum ribes $L$. is a plant from the indigenous Asian Polygonaceae (probably Siberian or Himalayan) cultivated in Europe since the sixteenth century (8). $R$. ribes $L$. is abundant in the Binalud Neyshabur slopes, in the mountains of Azerbaijan and Kurdistan, and in the Alborz highlands in northern Tehran, as well as in the Khorasan Razavi province of Gonabad province and in the mountains of Rabat Turk village (9). $R$. ribes $L$. has both medicinal and oral uses. $R$. ribes $L$. is a carrier of bile salts, a stimulant of bile salt secretion from the liver, laxative, gastric tonic, blood purifier and anti-parasite [10-13]. R. ribes $L$. contains some elements such as potassium calcium and is also rich in vitamins. The $R$. ribes $L$. petiole, which is a usable part, contains some organic acids, such as malic acid, which are useful for relieving thirst and facilitating digestion. It is also used in the traditional medicine of $R$. ribes $L$. to disperse some harmful bacteria [14-15]. However, antibacterial effects of this plant have been reported on some Gram-negative bacteria [16]. Hyssopus officinalisis from the Lamiaceae family is a perennial, very aromatic, with numerous stems of 20 to 60 $\mathrm{cm}$ height that grow in southern Europe, Asia Minor, Iran and Russia. [17-18]. this plant has anti-inflammatory, antibacterial, antiinflammatory, anti-spasmodic, antihypertensive and anti-cancer properties [19]. The aim of this study was to investigate the antibacterial properties of $R$. ribes $L$. and $H$. officinalisis in vitro on standard bacteria.

\section{Materials and Methods}

In this in vitro study, plants were collected from the natural areas of Marand city during two stages of one month interval from May to June 2019. Samples were collected carefully from a geographical area and hand-picked. After collection, nylon bags were used to transport the samples. The specimens are cleaned after collection and transport, and their waste materials such as pebbles, soil, other weeds, yellow leaves and stems and roots are separated from the specimens and in a large, convenient space and dried in the sun. After the specimens were completely dried and the shoots and leaves of the shoots were removed from the roots, they were prepared for grinding. Thus, to increase the level of contact of the plant parts with distilled water, they were powdered with electric milling. It is advisable to do this a few minutes before the extraction operation and to prevent the elevation of the mill temperature because high mill temperature affects the quality of the extract. Soxhlet extractoris used for extraction so that $300 \mathrm{~g}$ of the plant powder is poured into filter paper and soaked in a little methanol and put into the Soxhlet extractor. Laboratory flask containing $500 \mathrm{ml}$ of methanol are attached to the Soxhlet and heated then rotary to obtain pure extract. Then, using 5\% DMSO (CinnaGen Co, Iran)solvent, concentrations of $50 \mathrm{mg} / \mathrm{ml}$, $100 \mathrm{mg} / \mathrm{ml}, 200 \mathrm{mg} / \mathrm{ml}, 400 \mathrm{mg} / \mathrm{ml}$ were prepared for use in disk diffusion test and MIC / MBC determination (according to CLSI protocol) (20). Staphylococcus aureus (ATCC: 25923), Bacillus cereus (PTCC: 
1052), Escherichia coli (ATCC: 25922), Pseudomonas aeruginosa (ATCC: 27853) strains are lyophilization from Pasteur Institute of Iran. In this method, the bacteria first were tested with a standard suspension of McFarland's equivalent of standard 0.5 McFarland and dispersed by sterile swabs of each bacterial sample to the surface of the Mueller-Hinton agar medium(MERCK CO, Germany). Immediately above the culture medium, wells of $5 \mathrm{~mm}$ in diameter and $2 \mathrm{~cm}$ apart were introduced and a certain amount of the dilution of the extract first referred to was inoculated into the well. Streptomycin antibiotic was used as positive control and DMSO as negative control. After completion of the work, all media were incubated for 24 hours at $37^{\circ} \mathrm{C}$ and finally the diameter of the bacterial growth holes was measured by a caliper (21-22). The diameter of the auras in the culture medium is a reaction to the concentration of the extract tested. This phenomenon is a linear relationship between the halo and the logarithm of the concentration of the extract that is determined by measuring the diameter of the growth halo and comparing it to a specific standard, the antimicrobial potency of the extract being tested [23]. The disc diffusion method is similar to the diffusion method, with disks impregnated with different concentrations of methanolic extract rather than agar surface. The method is to first extract the concentrations of $50 \mathrm{mg} / \mathrm{ml}, 100 \mathrm{mg} / \mathrm{ml}$, $200 \mathrm{mg} / \mathrm{ml}, 400 \mathrm{mg} / \mathrm{ml}$, and sterilize the sterile blanc disks and allow them to dry. After dipping the sterile swab in the microbial suspension, the excess solution was removed by pressing the swap to the side of the tube and then stretched across the plate. Streptomycin (PADTANTEB Co, Iran) antibiotic was used as positive control and DMSO as negative control. Plates were incubated at $37^{\circ} \mathrm{C}$ for $16-18 \mathrm{~h}$, then measured using a caliper for the growth zone diameter in millimeters [24]. Tests for determination of Minimum Inhibitory Concentration (MIC) and minimum bactericidal concentration (MBC) were performed by Tube dilution. For determination of MIC from methanolic extract, dilution series of 0.78 and 1.56, 3.25, $6.25,12.5,25,50,100,200, \mathrm{mg} / \mathrm{ml}$ in Muller Hinton broth culture medium(MERCK CO, Germany). Then, $1 \mathrm{ml}$ of the prepared microbial suspension was added to each dilution. A positive control tube with microbes (culture medium containing bacterial, no extract) and a negative control tube with contents (bacterial culture medium) were also prepared. After completion, all tubes were transferred to an incubator at $37^{\circ}$ C for 24-48 h. After incubation, the tubes were examined for opiate-induced inoculation of bacterial growth. The least dilution of the extract with no opacity (non-growth) was considered as MIC. To determine the minimum bactericidal concentration of extracts (MBC) from all tubes in which no growth was observed. The culture medium was cultured on Muller-Hinton Agar. The inoculated media were incubated for 24 hours at $37^{\circ} \mathrm{C}$, a plate containing the lowest concentration of extract and no bacterial growth observed as MBC of the extract concentration [25]. SPSS software version 18 was used to analyze the data. In order to study the significant difference was found between the results of ANOVA and Chi-square and the difference between the groups was significant at the significance level of $p<0.05$.

\section{Results}

Using the well diffusion and disk diffusion method and the effect of methanolic extracts of Reum ribes L. and Hyssopus officinalis on the tested bacteria, it was found that these extracts had a significant inhibitory effect on 
the tested bacteria and the higher the concentration of the methanolic extract, the greater the inhibitory effect. This study showed that the inhibitory effect of Reum ribes L. and Hyssopus officinalis methanolic extracts on Gram-positive bacteria is more than gram-negative bacteria. The results of the effect of different concentrations of methanolic extracts by well diffusion and disk diffusion methods are presented in Tables 1 and 2. These two methods differed in the size of the inhibition zone of these bacteria. MBC / MIC analysis showed that the extract of medicinal plants had the highest susceptibility to $B$. cereus and the least susceptibility to $E$. coli. The results of MBC / MIC test of methanolic extracts against selected bacteria by tubular method are presented in Table 3.

Table 1. The diameter of inhibition zone at different concentrations of methanolic extracts by well diffusion method (mm)

\begin{tabular}{|c|c|c|c|c|c|c|}
\hline \multicolumn{7}{|c|}{ Methanolic extracts of Reum ribes $L$} \\
\hline $\begin{array}{l}\text { Bacteria / } \\
\text { Concentrate } \\
\text { Extract }\end{array}$ & $50 \mathrm{mg} / \mathrm{ml}$ & $100 \mathrm{mg} / \mathrm{ml}$ & $200 \mathrm{mg} / \mathrm{ml}$ & $400 \mathrm{mg} / \mathrm{ml}$ & $\begin{array}{c}\text { Positive } \\
\text { control }\end{array}$ & Negative control \\
\hline $\begin{array}{l}\text { Staphylococcus } \\
\text { aureus }\end{array}$ & 8 & 9.24 & 11.69 & 13.64 & - & 18.09 \\
\hline Bacillus cereus & 7.68 & 9 & 11.38 & 13.11 & - & 17.3 \\
\hline $\begin{array}{l}\text { Pseudomonas } \\
\text { aeruginosa }\end{array}$ & -- & 7.4 & 8.55 & 10.67 & - & 13.6 \\
\hline $\begin{array}{l}\text { Escherichia } \\
\text { coli }\end{array}$ & -- & -- & 7.69 & 9.38 & - & 14.57 \\
\hline \multicolumn{7}{|c|}{ Methanolic extracts of Hyssopus officinalis } \\
\hline $\begin{array}{c}\text { Staphylococcus } \\
\text { aureus }\end{array}$ & -- & 8.29 & 10.46 & 12.41 & - & 17.41 \\
\hline Bacillus cereus & -- & -- & 9.82 & 11.6 & - & 16.9 \\
\hline $\begin{array}{c}\text { Pseudomonas } \\
\text { aeruginosa }\end{array}$ & -- & -- & 8.7 & 10.2 & - & 14.5 \\
\hline $\begin{array}{l}\text { Escherichia } \\
\text { coli }\end{array}$ & -- & -- & 7.7 & 9.9 & - & 15 \\
\hline
\end{tabular}


Table 2. The diameter of inhibition zone at different concentrations of methanolic extracts by disk diffusion method (mm)

\begin{tabular}{|l|c|c|c|c|c|c|}
\hline \multicolumn{7}{|c|}{ Methanolic extracts of Reum ribes L } \\
\hline $\begin{array}{l}\text { Bacteria / } \\
\begin{array}{l}\text { Concentrate } \\
\text { Extract }\end{array}\end{array}$ & $50 \mathrm{mg} / \mathrm{ml}$ & $100 \mathrm{mg} / \mathrm{ml}$ & $200 \mathrm{mg} / \mathrm{ml}$ & $400 \mathrm{mg} / \mathrm{ml}$ & $\begin{array}{c}\text { Positive } \\
\text { control }\end{array}$ & Negative control \\
\hline $\begin{array}{l}\text { Staphylococcus } \\
\text { aureus }\end{array}$ & 7.32 & 9.12 & 11 & 13.21 & - & 17.66 \\
\hline Bacillus cereus & 7.2 & 9.24 & 11.85 & 13.41 & - & 17.17 \\
\hline $\begin{array}{l}\text { Pseudomonas } \\
\text { aeruginosa }\end{array}$ & -- & 8 & 9.74 & 11.2 & - & 14.55 \\
\hline $\begin{array}{l}\text { Escherichia } \\
\text { coli }\end{array}$ & -- & -- & 8 & 10.74 & - & 14.73 \\
\hline \multicolumn{2}{|l|}{} & - Methanolic extracts of Hyssopus officinalis & \\
\hline $\begin{array}{l}\text { Staphylococcus } \\
\text { aureus }\end{array}$ & -- & 7.65 & 9.87 & 11.74 & - & 18.21 \\
\hline Bacillus cereus & -- & -- & 8.4 & 10.2 & - & 17.24 \\
\hline $\begin{array}{l}\text { Pseudomonas } \\
\text { aeruginosa }\end{array}$ & -- & -- & 8.1 & 10.71 & - & 15.76 \\
\hline $\begin{array}{l}\text { Escherichia } \\
\text { coli }\end{array}$ & -- & -- & 7.27 & 9.1 & - & \\
\hline
\end{tabular}

Table 3. MBC / MIC test of bacteria at different concentrations (mm)

\begin{tabular}{|l|c|c|}
\hline \multicolumn{3}{|c|}{ Methanolic extracts of Reum ribes $\boldsymbol{~}$} \\
\hline Bacteria / Concentrate Extract & MIC mg/ml & MBC mg/ml \\
\hline Staphylococcus aureus & 12.5 & 50 \\
\hline Bacillus cereus & 12.5 & 25 \\
\hline Pseudomonas aeruginosa & 25 & 50 \\
\hline Escherichia coli & 50 & 100 \\
\hline \multicolumn{2}{|c|}{ Methanolic extracts of Hyssopus officinalis } \\
\hline Staphylococcus aureus & 25 & 50 \\
\hline Bacillus cereus & 25 & 50 \\
\hline Pseudomonas aeruginosa & 50 & 100 \\
\hline Escherichia coli & 50 & \\
\hline
\end{tabular}




\section{Discussion}

Due to the increasing resistance of bacteria to a variety of antibiotics, efforts have been made to obtain and use the compounds present in plants and their application in the treatment of various diseases. Plants have played an important role in maintaining health and improving the quality of life of humans for thousands of years. Medicinal herbs have useful properties such as antimicrobial, antiparasitic, antifungal and antioxidant properties. Medicinal herbs are those groups of herbs that are used for medical, therapeutic, clinical, and pharmacological purposes [10]. According to research by Dehghanzadeh et al., Essential oils of Reum ribes $L$ have carvacrol $(7.73 \%)$ and thymol (18.95\%) [26 29]. Carvacrol results in the depletion of proton flux and depletion of ATP, so that measurement of ATP levels inside and outside the cell indicates that after the presence of caroacrole in the medium the intracellular ATP level decreases and increases steadily outside the cell. According to the results of this study, gram-positive bacteria are more susceptible to plant extracts, which is similar to the results of previous studies on gram-positive and gram-negative bacteria [31-31]. The reason for the sensitivity of gram-positive bacteria to chemicals and essential oils and plant extracts is the difference in wall structure. Gram-positive bacteria have a mucopeptide in their cell wall, whereas gram-negative bacteria only have a thin layer of mucopeptide and most of the wall structure is lipoprotein and lipopolysaccharide. In fact, Gram-negative bacteria have an outer membrane around their cell wall, which makes them more resistant to antibacterial substances [32]. Degradation of the cell wall results in the leakage of cellular contents outward resulting in cell death. The effect of these compounds depends on the dose and duration of their action. Higher concentrations will increase the rate of destruction of the microorganisms, As a result, more time should be used to produce similar antibacterial effects at low doses [30]. Hovadik and Chladek reported that Hyssopus officinalis had the highest antibacterial effect [33]. Hassanshahiyan et al., by analyzing the antimicrobial effects of Hyssopus officinalis extract, showed that the maximum inhibitory effect of these extracts was against $S$. aureus and $P$. aeruginosa. The inhibitoriest effects of ethanolic extract of Hyssopus officinalis on biofilm formation against E. coli $(95 \%)$ were observed [34]. Burfer reported in a study in 2014 that the ethanolic extract of Reum ribes $L$ has antibacterial properties on $S$. aureus, $K$. pneumoniae and E. coli [35]. One study showed that the extract obtained from Reum ribes $L$ leaves had significant antibacterial activity [16]. Salehi et al. (2016), by studying the aqueous and ethanolic extracts of Reum ribes $L$, showed that the inhibitory effect of aqueous and ethanolic extracts of Reum ribes $L$ stems and leaves on $S$. aureus was more than that of E. coli. The highest diameter of non-growth zone at concentration of $150 \mathrm{mg} /$ $\mathrm{ml}$ was related to ethanolic and aqueous extracts of Reum ribes $L$. stalk on $S$. aureus which was $23 \pm 1.3$ and $16 \pm 1.1 \mathrm{~mm}$ respectively [36].

\section{Conclusion}

Since Reum ribes $L$. and Hyssopus officinalis extracts have higher antibacterial activity, identifying the effective material of these plants as an effective antimicrobial compound is the next step in this direction and it is necessary to identify the antimicrobial effects of other plants of the same family with these plants. 


\section{Acknowledgements}

The project is code 93397 with the financial support of the Young Researchers and Elite Club, Ahar Branch, Islamic Azad University, Ahar, Iran. The authors therefore acknowledge the efforts of the respected officials of the Young Researchers and Elite Club, Ahar Branch.

\section{Declarations}

\section{Conflict of interest}

We declare that we have no financial or nonfinancial conflicts of interest related to the subject matter or materials discussed in the article.

\section{Authors' contributions}

All authors contributed equally to this work 


\section{References}

1. Skaltsa H, Lazari DM, Chinou IB, Loukis AE.Composition and antibacterial activity of the essential oils of Stachys candida and S. chrysantha from Southern Greece. Planta Med. 1999;65 (3): 255- 256. [DOI:10.1055/s-2006960471]

2. Jafari-Sales A, Jafari B, Sayyahi J, ZohooriBonab T. Evaluation of antibacterial activity of ethanolic extract of malva neglecta and althaea officinalis 1. On antibiotic-resistant strains of staphylococcus aureus. J Biol Today World. 2015;4(2):58-62.

\section{[DOI:10.15412/J.JBTW.01040205]}

3. Mobaiyen H, Jafari Sales A, Sayyahi J. Evaluating antimicrobial effects of centaurea plant's essential oil on pathogenic bacteria: staphylococcus aureus, staphylococcus epidermidis, and escherichia coli isolated from clinical specimens. Journal of Fasa University of Medical Sciences. 2016 Mar 15;5(4):479-87.

4. Jafari-Sales A, Hossein-Nezhad P. Antimicrobial effects of Rosmarinus officinalis methanolic extract on Staphylococcus aureus, Bacillus cereus, Escherichia coli and Pseudomonas aeruginosa in laboratory conditions. Journal of Medicinal and Chemical Sciences. 2019 Sep 2:103-8.

5. Jafari-sales A, Shadi-Dizaji A. Evaluation of Inhibitory Effect of Methanol Extract of Allium Sativum in vitro on Staphylococcus aureus and Escherichia coli. Scientific Journal of Nursing, Midwifery and Paramedical Faculty. 2019 Jul 10;5(1):61-8

6. WHO Traditional Medicine Strategy 20022005, Geneva. 2002;1-3:43-47.

7. Jafari-Sales A, Bolouri P. Evaluation of the antimicrobial effects of Glycyrrhiza glabra 1. on some gram positive and gram negative pathogenic bacteria in laboratory conditions. Jorjani Biomed $\begin{array}{lllll}\text { J. } & 2018 ; & 6 & \text { (4) }\end{array}$ [DOI:10.29252/jorjanibiomedj.6.4.78]
8. Ozturk M, Ozturk FA, Duru ME, Topcu G. Antioxidant activ-ity of stem and root extracts of Rhubarb (Rheum ribes): An ed-ible medicinal plant. Food Chemistry. 2007; 103(2):623-30. doi: 10.1016/j.foodchem.2006.09.005 [DOI:10.1016/j.foodchem.2006.09.005]

9. Onder Turkmen, Mustafa C rka, Suat E. Initial Evaluation of a New Edible Wild Rhubarb Species (Rheumribes L.) with a Modified Weighted Scaling Index Method. Pakistan Journal of Biological Sciences 2005; 8: 5, 763 - 5. [DOI:10.3923/pjbs.2005.763.765]

10. zargari A. Rhubarbes. Medicinal plant. Volum 4: Sixt edition. Tehran University publication. 1997, pp: 234 - 9. 96Downloaded from jmp.ir at 15:25 +0430 on Tuesday May 21st 2019

11. Qasemi dehkardy n. Rheumpalmatum L. Iranian herbal pharmacopoeia. 1st ed. Health Ministery press. Tehran Iran. 1381, pp: 342 - 9

12. Giasudin Jazaieri. Zaban Khorakiha. 1983, Volume 1, pp: 39 - 41

13. Gollan, W. (1992). Indian Vegetable Plantation. Akashdeep Publishing House. Delhi , India.

14. Ozcan MM, Dursun N, Arslan D. Some nutritional properties of Prangos ferulacea (L.) Lindl and Rheumribes L. stems growing wild in Turkey. Int. J. Food Sci. Nutr. 200758 (2): 162 7. [DOI:10.1080/09637480601154145]

15. Fatma TOSUN, Çiğdem AKYÜZ KIZILAY Anthraquinones and Flavonoids from Rheum ribes. Ankara Ecz. Fak. Derg. 2003; 32 (1): 31 - 5.

16. Bazzaz F, Khajehkaramadin M, Shokooheizadeh HR. In vitro antibacterial activity of Rheum ribes extract obtained from various plant parts against clinical isolates of Gramnegative pathogens. Iranian Journal of Pharmaceutical Research. 2010 Nov 20:87-91.

17. Khoshnood-Mansoorkhani MJ., Moein MR., Oveisi N. Anticonvulsant activity of Teucrium polium against seizure induced by PTZ and MES in mice. Iranian Journal of Pharmaceutical 
Research: IJPR2010; 9 (4): 395-401. PMCID: PMC3870063.

18. Azizi H., Keshavarzi M. Ethnobotanical study of medicinal plants of Sardasht, western Azerbaijan, Iran. Journal of Herbal Drugs (An International Journal on Medicinal Herbs)2015; 6 (2): 113-9. www.jhd.iaushk.ac.ir.

19. Ardestani A., Yazdanparast R. Inhibitory effects of ethyl acetate extract of Teucrium poliumon in vitro protein glycoxidation. Food and chemical toxicology : an international journal published for the British Industrial Biological Research Association2007; 45 (12): 2402-11. DOI:10.1016/j.fct.2007.06.020.

[PubMed: 17673348]. [DOI:10.1016/j.fct.2007.06.020]

20. Stojano vic G, Radulovic N, Hashimoto T, Palic R. In vitro antimicrobial activity of extracts of four Achillea species: The composition of Achillea clavennae L. (Asteraceae) extract. J Ethnopharmacol 2005; 101 (1 - 3): 185 - 10 [DOI:10.1016/j.jep.2005.04.026]

21. Kim J, Kuk E, Nam Yu K, Kim JH, Park SJ, Lee HJ. Antimicrobial effects of silver nanoparticles. Nanomedicine: Nanotechnology, Biology, and edicine. 2007;3:95- 101. [DOI:10.1016/j.nano.2006.12.001]

22. Sattari M, Shahbazi N, Najar Peeryeh S. An assessment of antibacterial effect of alcoholic and aquatic extracts of Eucalyptus leaves on Pseudomonas aeruginosa. J Med Sci. 2006;8(5):19-23

23. Neef H, Declercq P, Laekeman G. Hypoglycaemic activity of selected European plants. Phytother Res 1995; 9:45-48. [DOI:10.1002/ptr.2650090111]

24. Shariff ZU. Modern herbal therapy for common ailments. Nature pharmacy series In Spectrum Books limited2001;1:9-84.

25. Alizadeh H, Jafari B, Babai T, The Study of Antibacterial Effect of Capsella BursaPastoris on Some of Gram Positive and Gram Negative
Bacteria. Journal of Basic and Applied Scientific Research 2012; 2 (7): 6940 - 6945.

26. Dehghanzadeh, N., Ketabchi, S. and Alizadeh, A. 2012. Essential oil composition and antibacterial activity of Hyssopus officinalis L. grown in Iran. Asian Journal of Experimental Biological Science.3(4): 767- 771.

27. Hashemi, P., Abolghasemi, M., Fakhari, A., Ebrahimi, S. and Ahmadi, S. 2007. Hydrodistillation-solvent microextraction and GC-MS identification of volatile components of Artemisia aucheri . Chromatographia. 66: 283286. [DOI:10.1365/s10337-007-0289-4]

28. Farzaneh, M., Ahmadzadeh, M., Hadian, J. and Tehrani, A.S. 2006. Chemical composition and antifungal activity of essential oils of three species of Artemisia on some soil borne phytopathogens. Communications in Agricultural and Applied Biological Sciences. 71(3): 13271333.

29. Ghorbani-Ghouzhdi, H., Sahraroo, A., Asghari, H. and Abbasdokht, H. 2008. Composition of essential oils of Artemisia sieberi and Artemisia Khorasanica from Iran. World Applied sciences Journal. 5(3): 363-366.

30. Burt, S. 2004. Essential oils: Their antibacterial properties and potential applications in foods: A review. International Journal of Food Microbiology . 94(3): 223-253 [DOI:10.1016/j.ijfoodmicro.2004.03.022]

31. Skandamis, P., Koutsoumanis, K., Fasseas, K.and Nychas, G.-J.E. 2001. Inhibition of oregano essential oil and EDTA on Escherichia coli O157:H7. Italian Journal of Food Science. 13(1): 65-75

32. Soltani Nezhad, Sh., Mokhtari Sataeei, T. and Soltani Nezhad, M. 2010. Evaluation of antibacterial activity of eucalyptus leaf extract against Staphylococcus aureus, Escherichia coli and Streptococcus pyogenes in vitro, Journal of Islamic Azad University of Microbial Biotechnology. 4: 21-28. 
33. HOVADIK, A.; CHLADEK, M., 1974: The antimicrobial activity of the essential oils of some aromatic plants. Bulletin, Vyzkumny Ustav Zelinarsky Olomouc (18): 61-71.

34. Hassanshahiyan, M., Saadatfar, A., Masoumi, F. Antimicrobial properties of Hyssopus officinalis extract against antibiotic-resistant bacteria in planktonic and biofilm form. Biological Journal of Microorganism, 2018; 7(28): 91-101. doi: 10.22108/bjm.2017.105971.1080
35. Burfer, Jacob, Antibacterial activity of rhubarb hydroalcoholic extract on Staphylococcus aureus, Klebsiella pneumoniae and Escherichia coli, the first national congress of biology and natural sciences of Iran, 2014.

36. Salehi, A., Shariatifar, N., Salehi, A., Mohammadzadeh, A. In-Vitro Antimicrobial Effect of Aqueous and Alcoholic Extracts of Rheum Ribes on Some Food-Borne Pathogens. Journal of Sabzevar University of Medical Sciences, 2016; 23(3): 430-437. doi: 10.21859/sums-2303430 [DOI:10.21859/sums2303430]

\section{How to cite:}

Sayyahi J, Mobaiyen H, Jafari B, Jafari-Sales A. Antibacterial effects of methanolic extracts of Reum ribes L. and Hyssopus officinalis on some standard pathogenic bacteria. Jorjani Biomedicine Journal. 2019; 7(3): 34-44 